\title{
Performance of Direct Seeded Upland Rice (Oryza sativa L) as Influenced by Seed Priming and Micro-Nutrients in Old Alluvial Zone of West Bengal, India
}

\author{
Tapas Kumar Pandit* and Saikat Mookherjee
}

Regional Research Station (Old Alluvial Zone), Uttar Banga Krishi Viswavidyalaya, Majhian, Dakshin Dinajpur, West Bengal-733133, India

*Corresponding author

\section{A B S T R A C T}

A field experiment was conducted during kharif 2015-16 and 2016-17 at the Regional Research Station (Old Alluvial Zone), Dakshin Dinajpur under Uttar Banga Krishi

\section{Keywords}

Direct seeded rice, Micronutrients, Seed priming, Yield.

Article Info

Accepted:

21 September2017

Available Online:

10 October 2017 Viswavidyalaya to study the effect of seed priming and foliar application of micronutrients on direct seeded upland rice (Oryza sativa $\mathrm{L}$ ). The experiment was laid out in factorial randomized block design with nine treatment combinations comprising seed priming and foliar spray of micronutrients. Treatments were replicated thrice. Significantly highest yield $\left(3667.03 \mathrm{~kg} \mathrm{ha}^{-1}\right)$ was recorded in seed priming with $2.2 \% \mathrm{CaCl}_{2}$. This priming treatment also had greater impact in production economics (return rupee ${ }^{-1}$ of investment is 1.45) of direct seeded rice. The rice seed priming with water showed poor productivity leading to less remuneration. Foliar spray with chelated zinc and solubor at 35 and 55 DAS respectively showed improvement in yield components and yield of direct seeded rice $\left(3546.98 \mathrm{~kg} \mathrm{ha}^{-1}\right)$ compared to sole application of chelated zinc and solubor at 35 and 55 DAS. Return rupee ${ }^{-1}$ of investment (1.42) was highest when direct seeded rice crop received two foliar spray with chelated zinc and solubor at 35 and 55 DAS. No remarkable changes have been observed in $\mathrm{pH}$, available $\mathrm{N}, \mathrm{P}_{2} \mathrm{O}_{5}$ and $\mathrm{K}_{2} \mathrm{O}$ status in the soil after two years of the experiment.

\section{Introduction}

Old alluvial zone in the northern tract of the West Bengal state of India is one of the prominent rice growing belts. Traditionally rice in this zone is grown by transplanting of certain aged seedlings in to the puddled field. Transplanted rice requires a continuous supply of water throughout its growth and development period (Farooq et al., 2007). Transplanting of rice is labour intensive and sometimes it cause delayed transplanting due to crisis in availability of labour which ultimately fetches a lower productivity and poor return (Farooq et al., 2011).
The rice cultivation practice in this old alluvial zone of West Bengal, is not standing in the place of exception. Sometimes delayed transplanting with the aged seedlings results lower productivity of upland rice in this zone due to uneven distribution of rainfall. Direct seeded rice culture is an alternative cost effective technology which requires less labour and water than conventional transplanted rice (Balasubramanian and Hill 2002; Farooq et al., 2011). But good crop establishment has the vital role in the production of the direct seeded rice crop. 
Sometimes uneven and patchy establishment in direct seeded rice result low yields which in present day becoming a hindrance to popularize the technology of direct seeding in the old alluvial zone.

Delay in germination and slower rate seedlings establishment in the field are the main problems in direct seeded method. Du and Toung, 2002 reported that, poor seedling establishment is one of the major yield limiting constraints both in transplanted and direct seeded rice. Harris et al., (1999) reported that, seed priming is one of the most important development to help rapid and uniform germination and emergence of seeds. Seed priming is a technology which practically ensures rapid and uniform germination with lower percentage of abnormal seedlings (Singh, 1995; Shivankar et al., 2003). Seed priming is a procedure in which seed is soaked in water and then dried back to its original moisture content (Harris et al., 2002). Seed priming is a hydration treatment that allows controlled imbibition and induction of pre-germinate metabolism (Gurusinghe et al., 1990 and Gallardo et al., 2001).Deficiency of boron (B) and zinc ( $\mathrm{Zn}$ ) is a major factor constraining crop production on acidic soils of Northeast India (Manoj Kumar et al., 2016); Due to inherent acidity, this zone is deficient in micronutrient status in soil especially zinc ( $\mathrm{Zn}$ ) and boron (B).Zinc mostly absorb through soil solutions and has a significant role in plant enzymatic systems as structural catalyst and interferes in proteins destruction in plant cells; EDTA ethylene diamine tetra-acetic acid, a chelating agent used for soluble micronutrient fertilisers which translocate quickly with in the plant system. Malakoti and Keshavarz, (2003) reported that boron $(\mathrm{B})$ is one of the important elements that have the effects on fruit formation and transfer of photosynthetic components. The first visible sign of deficiency of $\mathrm{B}$ in plants is prevention of terminal bud growth which leads to death of new leaves. It is the fact, foliar application of fertilizers and micronutrients is more suitable in comparison with the other types of applications (Noor et al., 2004).

Keeping in view of the fact an experiment was undertaken to assess the effect of seed priming using agro-chemicals and foliar spray of zinc and boron on direct seeded upland rice at old alluvial zone of West Bengal, India.

\section{Materials and Methods}

The field experiment was conducted at the farm of Regional Research Station (Old Alluvial Zone), Uttar Banga Krishi Viswavidyalaya, Majhian, Dakshin Dinajpur, West Bengal, India in two consecutive years, viz., 2015-16 and 2016-17during kharif. The farm is situated at $26^{\circ} 19^{\prime} 86^{\prime \prime} \mathrm{N}$ latitude and $89^{0} 23^{\prime} 53^{\prime \prime}$ E longitude and at an altitude of 43 meter above mean sea level. This old alluvial zone is characterized by annual rainfall of 1500-1700 mm and pre-humid condition. The soil of the experimental site was texturally clay loam in nature. The status of available nitrogen, phosphorus and potash in the experimental soil were medium, low and low respectively with slightly acidic in reaction.

The experiment was laid out infactorial randomized block design with nine treatment combinations in plot size of $4 \mathrm{~m} \times 3 \mathrm{~m}$ and replicated thrice. Chelated zinc (12\% EDTA Zinc) and solubor (20\% Boron) were used as the sources of zinc and boron in this treatment schedule. The treatments comprised of the combination of seed priming using different agrochemicals and water $\left(\mathrm{P}_{0}=\right.$ Seed priming with water; $\mathrm{P}_{1}=$ Seed priming with $2.2 \%$ $\mathrm{NaCl} ; \mathrm{P}_{2}=$ Seed priming with $\left.2.2 \% \mathrm{CaCl}_{2}\right)$ and foliar spray with micronutrients $\left(\mathrm{S}_{1}=\right.$ foliar spray with Chelatedzinc at 35 DAS and 55 DAS; $S_{2}=$ Foliar spray of Chelated Zinc at 35 DAS + Foliar spray of Solubor at 55 DAS; 
$\mathrm{S}_{3}=$ Foliar spray of solubor at 35 and 55 DAS). In treatment combination under study, the recommended dose of fertilizer (60:30:30 $\mathrm{kg} \mathrm{N}, \mathrm{P}_{2} \mathrm{O}_{5}$ and $\mathrm{K}_{2} \mathrm{O}$ ha ${ }^{-1}$ ) was used as a source of major primary plant nutrients. For seed priming, solutions were prepared by dissolving $22 \mathrm{~g}$ of $\mathrm{NaCl}$ and $\mathrm{CaCl}_{2}$ separately in distilled water and volume was made up to $1000 \mathrm{ml}$. The seeds were then soaked with water, $\mathrm{NaCl}$ and $\mathrm{CaCl}_{2}$ as per the treatment schedule and allowed to absorb moisture up to 35 per cent of their weight and kept in imbibed condition for $6 \mathrm{hrs}$. and the seeds were spread out in a thin layer for drying under shade and subsequently in to sun to bring its moisture content up to $13 \%$. The dose of chelated zinc and solubor for foliar spray were used as $0.5 \mathrm{~g} \mathrm{lit}^{-1}$ and $2.0 \mathrm{~g} \mathrm{lit}^{-1}$ of water.

The rice variety IET-4094, popularly known as Khitish, was sown at $25 \mathrm{~cm}$ rows apart on June 26 and June 29 during 2015-16 and 2016-17 respectively. Fertilizers were applied in the plots as per treatments just after laying out of the experiment. Nitrogen was applied in three splits $(1 / 4$ at 15 DAS, $1 / 2$ at 30 DAS and rest $1 / 4$ at 45 DAS), while $3 / 4$ potassium was applied during final land preparation with $1 / 4$ as top dressing at 45 DAS. Entire phosphatic fertilizers were applied as basal. All other agronomic operations were performed as per recommendations of the crops. Economic analysis was carried out using the prevailing market price. Data were collected on growth attributes at different stages and yield components of rice. The statistical analysis of data was done following the procedure for analyzing factorial RBD (Cochran and Cox, 1977) and by using statistical software MSTAT-C version 2.1(Michigan State University, USA). Significant differences between the treatments were compared with the critical difference at $\pm 5 \%$ probability by LSD. The representative soil samples were analyzed following standard methods for ascertaining the available nutrients in soil at initial stage and after harvest of the crop.

\section{Results and Discussion}

The results in the table 1 revealed the significant effect of seed priming. Seed priming with $2.2 \% \mathrm{CaCl}_{2}$ showed maximum values in plant height $(114.67 \mathrm{~cm})$, Number of tillers $\mathrm{m}^{-2}(385.41)$, number of filled grain panicle $^{-1}(118.31)$ which ultimately reflected in significantly higher grain yield $(3667.03 \mathrm{~kg}$ $\mathrm{ha}^{-1}$ ) followed by seed priming with $2.2 \%$ $\mathrm{NaCl}$ and water. Seed priming devoid of any agro-chemical i.e. seeds primed with water showed poor values in plant height, number of tillers $\mathrm{m}^{-2}$, number of filled grain panicle ${ }^{-1}$ and grain yield in direct seeded rice.

There are three early phases in seed germination which are imbibition, lag phase and protrusion of the radicle (Simon, 1984). Priming affects the lag phase and causes early DNA replication, increased RNA and protein synthesis, greater ATP availability, faster embryo growth and repair of deteriorated seed parts (Mazor et al., 1984 and Saha et al., 1990). Calcium has a great role in protection of plants from any adverse effects during germination and thus improves the growth of plants perhaps due to the influence of $\mathrm{Ca}^{+2}$ on membranes and enhanced antioxidant proteins like Superoxide dismutase enzyme (Hameed et al., 2010). Lin and Kao, 1995 reported that $\mathrm{Ca}^{+2}$ also has a vital role in root growth of rice seedling. Uniform crop stand with developed root system in the treatment received seed priming with $2.2 \% \mathrm{CaCl}_{2}$ might have played a crucial role in uptake of more nutrients. Utilizing better light interception and greater nutrient uptake might be reflected in the higher values of plant height, number of tillers $\mathrm{m}^{-2}$, number of filled grain panicle ${ }^{-1}$ of direct seeded upland rice primed with $2.2 \%$ $\mathrm{CaCl}_{2}$ which ultimately converted in to yield which is $26.43 \%$ higher than the priming with water. 
Table.1 Plant height, no. of effective tillers $\mathrm{m}^{-2}$, no. of filled grains panicle ${ }^{-1}$, grain yield and return rupee ${ }^{-1}$ invested of direct seeded upland rice (Variety: IET-4094) as influenced by seed priming and micronutrients at OAZ

\begin{tabular}{|c|c|c|c|c|c|}
\hline Seed Priming & $\begin{array}{c}\text { Plant height }(\mathrm{cm}) \text { at } \\
100 \text { DAS }\end{array}$ & $\begin{array}{l}\text { No. of effective } \\
\text { tillers } \mathbf{~ m}^{-2}\end{array}$ & $\begin{array}{c}\text { No of filled } \\
\text { grains panicle }^{-1}\end{array}$ & $\begin{array}{l}\text { Grain yield } \\
\mathrm{Kg} \mathrm{ha}^{-1}\end{array}$ & $\begin{array}{c}\text { Return INR }^{-1} \\
\text { invested }\end{array}$ \\
\hline Hydro priming & 85.13 & 321.95 & 81.56 & 2900.44 & 1.21 \\
\hline Priming with $\mathrm{NaCl}(2.2 \%)$ & 97.35 & 355.42 & 105.48 & 3253.00 & 1.29 \\
\hline Priming with $\mathrm{CaCl}_{2}(2.2 \%)$ & 114.67 & 385.41 & 118.31 & 3667.03 & 1.45 \\
\hline SEm (+) & 4.90 & 6.22 & 5.35 & 125.34 & - \\
\hline C.D $(P=0.05)$ & 14.69 & 18.63 & 16.05 & 375.73 & - \\
\hline \multicolumn{6}{|l|}{ Micronutrient Spray } \\
\hline Chelated zinc at 35 and 55 DAS & 95.31 & 342.35 & 86.35 & 2956.41 & 1.25 \\
\hline $\begin{array}{l}\text { Chelated zinc at } 35 \text { DAS + } \\
\text { Solubor } 55 \text { DAS }\end{array}$ & 102.63 & 365.61 & 116.28 & 3546.98 & 1.42 \\
\hline Solubor at 35 and 55 DAS & 99.21 & 354.82 & 102.72 & 3317.08 & 1.28 \\
\hline SEm (+) & 4.90 & 6.22 & 5.35 & 125.34 & - \\
\hline C.D $(P=0.05)$ & NS & 18.63 & 16.05 & 375.73 & - \\
\hline
\end{tabular}

Table.2 Residual soil fertility status Residual fertility status after two years of experimentation

\begin{tabular}{|c|c|c|c|c|}
\hline Seed Priming & pH & Available N (Kg ha $\left.{ }^{-1}\right)$ & Available $\mathrm{P}\left(\mathrm{P}_{2} \mathrm{O}_{5} \mathrm{~kg} \mathrm{ha}^{-1}\right)$ & Available $\mathrm{K}\left(\mathrm{K}_{2} \mathrm{O} \mathrm{kg} \mathrm{ha}^{-1}\right)$ \\
\hline Hydro priming & 5.0 & 281.17 & 41.51 & 309.86 \\
\hline Priming with $\mathrm{NaCl}(2.2 \%)$ & 5.1 & 285.16 & 42.23 & 310.56 \\
\hline Priming with $\mathrm{CaCl}_{2}(2.2 \%)$ & 5.2 & 287.11 & 41.87 & 310.98 \\
\hline \multicolumn{5}{|l|}{ Micronutrient Spray } \\
\hline Chelated zinc at 35 and 55 DAS & 5.1 & 283.14 & 41.39 & 310.09 \\
\hline $\begin{array}{l}\text { Chelated zinc at } 35 \text { DAS + } \\
\text { Solubor } 55 \text { DAS }\end{array}$ & 5.2 & 286.12 & 42.09 & 310.23 \\
\hline Initial value: & 5.2 & 284.15 & 41.36 & 310.18 \\
\hline
\end{tabular}


Though no significant variation has been found in the plant height in direct seeded upland rice but differed significantly in number of filled grains panicle ${ }^{-1}$ and number of effective tillers $\mathrm{m}^{-2}$, grain yield due to variation in spraying schedule of micronutrients (Table 1). Spraying with chelated zincat 35 DAS and Solubor at 55 DAS has been found as the best treatment among the micronutrient spray schedule to achieve higher number of filled grain panicle ${ }^{1}(116.28)$ and effective tillers $\mathrm{m}^{-2}$ (365.61), grain yield $\left(3546.98 \mathrm{~kg} \mathrm{ha}^{-1}\right) .19 .98 \%$ increase in yield of direct seed rice was achieved due to foliar spray with chelated zinc at 35 DAS and solubor at 55 DAS over the foliar sprays of chelated zinc at 35 and 55 DAS. On the other side $6.93 \%$ higher yield was achieved with foliar spray of chelated zinc and solubor at 35 and 55 DAS respectively over the sole spay of solubor at 35 and 55 DAS.

Plant leaves act as a source for capturing light and assimilate production. Boron fertilization in foliage hasa role in growth stage of a plant to increase leaf area index by accumulating indole acetic acid and growth hormones (Zhou et al., 2016).Zn is involved in cell division in plant body which results increase in length and width of leaves (Zhu et al., 2015). Healthy leaves with proper length and width increases chlorophyll content (Samreen et al., 2013) which is the major factor for better photosynthesis. Yield is the combined effect of different related activities and traits. Increase in grain yield under foliar application of Zn (at 35 DAS) and B (at 55 DAS) might be attributed to notable expansion in entire yield related physiological traits controlled by zinc and boron both with higher translocation of carbohydrates in the grain compared to less expansion in yield related traits in sole application zinc and boron. During afield study, Malakouti (2008) also observed application of nitrogen, phosphorus and potassium in addition to zinc and boron resulted significant impact on grain yield and quality of rice as well as nutrient concentration into grain.

During production economics study it has been revealed that the seed priming treatment with $2.2 \% \quad \mathrm{CaCl}_{2}$ fetched a best return per rupee of invested (1.45) compared to seed priming with $2.2 \% \quad \mathrm{NaCl}$ (1.29) and hydropriming (1.21).The treatment schedule consisting foliar spray of chelated zinc and solubor at 35 and 55 DAS respectively showed highest return per rupee invested (1.42) compared to other spray schedule. No such remarkable change in residual fertility (Table 2) has been observed for the treatment combinations used in direct seeded upland rice.

Though no interaction effect was found between seed priming and foliar spray of micronutrient schedule but it can be concluded that the combination of seed priming with $2.2 \% \mathrm{CaCl}_{2}$ and micronutrient spray with chelated zinc at 35 DAS and Solubor at 55 DAS in addition to use recommended dose of fertilizer might be an option to increase productivity of direct seeded rice in old alluvial zone.

\section{References}

Balasubramanian, V., and Hill, J. E. 2002. Direct seeding of rice in Asia: emerging issues and strategic research needs for the $21^{\text {st }}$ century, 15-39. In: Pandey S, Mortimer M, Wade L, Tuong TP, Lopez K, Hardy B. (eds). Direct seedling: research strategies and opportunities. Manila (Philippines): International Rice Research Institute.

Cochran, W.G., and Cox, G.M. 1977. Experimental Design.Asia Publishing House, Calcutta, pp. 95-132 and 142181.

Du., L.V., and Tuong, T. P. 2002. Enhancing 
the performance of dry-seeded rice: effects of seed priming, seedling rate, and time of seedling. In: Direct seeding: Research strategies and opportunities. (eds). Pandey, S., M. Mortimer, L. Wade, T.P. Tuong, K. Lopes and B. Hardy. International Research Institute, Manila, Philippines, Pp. 241-256.

Farooq, M. Siddique., KHM. Rehman, H. Aziz., T. Lee., D.J. Wahid., A. 2011. Rice direct seedling: Experiments, Challenges and opportunities. Soil. Till. Res. 111:87-98.

Farooq, M., Basra, S. M. A. and Ahmad, N. 2007. Improving the performance of transplanted rice by seed priming. Plant Growth Reg. 51(2): 129-137.

Gallardo, K., Job, C. Groot., S.P. C. Puype, M. Demol, H. Vandekerckhove, J. and Job, D. 2001. Proteomic analysis of Arabidopsis seed germination and priming" Plant physiology, 126: 835848.

Gurusinghe, S. H., Z. Y. Cheng and K. J. Bradford, (1990). Cell Cycle Activity during Seed Priming is not essential for germination advancement in Tomato." Journal of Ex-perimental Botany, 50:101-106.

Doi:10.1093/jxb/50.330.101.

Hameed, A., Afzal I. and Iqbal, N. 2010. Seed priming and salinity induced variations in wheat (Triticumaestivum L.) leaf protein profile. Seed Sci Technol. 38:236-241.

Harris, D., Joshi, A. Khan., P.A. Gothkar, P. and. Sodhi, P.S. 1999. On-farm seed priming in semiarid agriculture: Development and evaluation in maize, rice and chickpea in India using participatory Methods. Exp. Agric., 35: 15-29.

Harris, D., Rashid, A. Hollington., P. A., Jasi., L. and Riches., C. 2002. Prospect of improving maize yields with 'on-farm' seed priming, 180-185. In: Rajbhandari,
N. P., Ransom J. K., Adikhari, R. A., Palme, F. E. (eds.). Sustainable Maize Production Systems for Nepal: Proceeding of Maize Symposium held at Kathmandu, Nepal, December 3-5, 2001. NARC and CIMMYT.

Lin., C. C., and Kao, C. H. 1995. $\mathrm{NaCl}$ stress in rice seedlings: the influence of calcium on root growth. Bot. Bull. Acad. Sin., 36:41-45.

Malakoti, M., Keshavarz., P. 2003. Boron place in plant efficient nutrition. 1st Ed., Sana Publication, Iran.

Malakouti., M.A., 2008. The effect of micronutrients in ensuring efficient use of macronutrients, Turk J. of Agric, 32: 215-220.

Manoj., K. A. K., Jha., S. Hazarika., B. C. Verma., B. U. Choudhury., T. Ramesh., P. Moirangthem., R. Kumar., Brajendra., D. J. Rajkhowa., A. Kumar., M. H. 2016). Devi National Academy Science Letters, 39: 85-89.

Mazor., L., Perl., M., and Negbi., M. 1984. Changes in some ATP-dependent activities in seed during treatment with polyethylene glycol and during redrying process. J. Exp. Bot. 35: 1119-1127.

Noor., A., Hosseinzadeh., A. Ghafari., M. 2004. Evaluation of planting date and foliar application of microelements of sunflower yield component. Proceeding of 3rd National Congress in Efficient Application of Fertilizers in Agriculture, (NCEAF'04), Iran, pp: 321326.

Saha, R., Mandal., A. K. and Basu., R. N. 1990. Physiology of seed invigoration treatments in soybean (Glycine max L). Seed Sci. and Tech. 18: 269-276.

Samreen, T., Humaira., Shah, H.U. SaleemUllah., Javid., M. 2013. Zinc effect on growth rate, chlorophyll, protein and mineral contents of hydroponically grown mung beans plant (Vigna radiate L.). Arabian J. Chem. 
Shivankar, R. S., Deore., D. B. and Zode, N. G. 2003. Effect of pre-sowing seed treatment on establishment and seed yield of sunflower. Journal of Oilseeds Research, 20:299-300.

Simon, E. W., 1984. Early events in germination. 77-115. In D.R. Murray (ed.) Seed physiology. (2), Germination and reserve mobilization. Academic Press, Orlando, FL.

Singh, B. G., 1995. Effect of hydrationdehydration seed treatments on Vigour and yield of sunflower. Indian Journal of Plant Physiology, 38:66-68.

Zhou, T., Hua, Y. Huang., Y. Ding., G. Shi., L. Xu., F. 2016. Physiological and Transcriptional Analyses Reveal Differential Phytohormone Responses to Boron Deficiency in Brassica napus Genotypes. Front. Plant Sci. 7:221.

Zhu., J., Zhang., K.X. Wang., W.S. Gong., W. Liu., W.C. Chen., H.G. 2015. Low temperature inhibits root growth by reducing auxin accumulation via ARR1/12. Plant Cell Physiol. 56, 727736.

\section{How to cite this article:}

Tapas Kumar Pandit and Saikat Mookherjee. 2017. Performance of Direct Seeded Upland Rice (Oryza sativa L) as Influenced by Seed Priming and Micro-Nutrients in Old Alluvial Zone of West Bengal. Int.J.Curr.Microbiol.App.Sci. 6(10): 2163-2169. doi: https://doi.org/10.20546/ijcmas.2017.610.256 